\title{
Validation of content of guidelines for people with peripheral neuropathy due to diabetes
}

\author{
Validação de conteúdo de um guia de orientações a pessoas com neuropatia periférica \\ por diabetes
}

\author{
Validación de contenido de una guía de orientaciones a personas con neuropatía \\ periférica por diabetes
}

Uiara Aline de Oliveira Kaizer ${ }^{1}$, Vanessa Soares de Araujo², Sonia Regina Perez Evangelista Dantas ${ }^{3}$

ORCID IDS

Kaizer UAO (D) https://orcid.org/0000-0002-9115-8043

de Araujo VS (D) https://orcid.org/0000-0003-0570-9038

Dantas SRPE (D) https://orcid.org/0000-0002-9639-8900

\section{HOW TO CITE}

Kaizer UAO; de Araujo VS; Dantas SRPE. Validation of content of guidelines for people with peripheral neuropathy due to diabetes. ESTIMA, Braz. J. Enterostomal Ther., 16: e2518. doi: 10.30886/estima. v16.582.

\begin{abstract}
Objective: A quantitative methodological approach with the objective of elaborating and validating the content of an educational instrument with health promotion actions for self-care of people with peripheral neuropathy due to diabetes. Methods: A bibliographic survey was realized on the subject in the databases of the Virtual Health Library, SciELO and LILACS/ Database of Nursing (BDENF) and elaborated a guide of recommendations for health promotion of people with diabetes, with educational texts and original photos. Validation of the educational guide was performed by a judges' committee for clarity, relevance and comprehensiveness, and the content validity index (CVI) of all items and subitems was calculated. Results: The instrument obtained the CVI of 0.89. Items and subitems $<0.8$ were modified or excluded, and the appearance of the material was considered good. Conclusion: The educational instrument obtained adequate agreement between the judges and was validated.
\end{abstract}

DESCRIPTORS: Diabetic foot; Diabetic neuropathies; Foot ulcer; Validation studies; Stomatherapy.

\footnotetext{
${ }^{1}$ Universidade Estadual de Campinas - Faculdade de Enfermagem - Programa de Pós-Graduação em Enfermagem - Campinas/SP - Brazil. ${ }^{2}$ Conjunto Hospitalar de Sorocaba - Comissão de Feridas Estomas e Incontinência - Sorocaba/SP - Brazil.

3Universidade Estadual de Campinas - Faculdade de Ciências Médicas - Curso de Especialização de Enfermagem em Estomaterapia - Campinas/SP - Brazil.

Corresponding author: Uiara Aline de Oliveira Kaizer | Universidade Estadual de Campinas - Faculdade de Enfermagem | Cidade Universitária Zeferino Vaz - Barão Geraldo | ZIP Code: 13083-970 - Campinas/SP - Brazil | E-mail: uiara_oliveira@hotmail.com Received: Mar. 302018 | Accepted: Sept. 102018
} 


\section{RESUMO}

Objetivo: Estudo de abordagem metodológica quantitativa com objetivo elaborar e validar o conteúdo de um instrumento educativo com ações de promoção de saúde para autocuidado de pessoas com neuropatia periférica por diabetes. Métodos: Foi realizado levantamento bibliográfico sobre o tema nas bases de dados Biblioteca Virtual Saúde, SciELO e LILACS/Banco de Dados em Enfermagem (BDENF) e elaborado um guia de recomendações para promoção da saúde de pessoas com diabetes, com textos educativos e fotos originais. A validação do guia educativo foi realizada por um comitê de juízes quanto à clareza, pertinência e abrangência, e calculado o índice de validade de conteúdo (IVC) de todos os itens e subitens. Resultados: O instrumento obteve o IVC de 0,89. Itens e subitens $<$ 0,8 foram modificados ou excluídos, e a aparência do material foi considerada boa. Conclusão: 0 instrumento educativo obteve concordância adequada entre os juízes e foi validado.

DESCRITORES: Pé diabético; Neuropatias diabéticas; Úlcera do pé; Estudos de validação; Estomaterapia

\section{RESUMEN}

Objetivo: Estudio de abordaje metodológico cuantitativo con el objetivo de elaborar y validar el contenido de un instrumento educativo con acciones de promoción de la salud para el autocuidado de personas con neuropatía periférica por diabetes. Métodos: Se realizó un relevamiento bibliográfico sobre este tema en las bases de datos de la Biblioteca Virtual Saúde, SciELO y LILACS/Banco de Datos en Enfermería (BDENF) y se elaboró una guía de recomendaciones para la promoción de la salud de personas con diabetes, con textos educativos y fotos originales. La validación de la guía educativa fue realizada por un comité de jueces en cuanto a la claridad, pertinencia y alcance, y calculado el índice de validez de contenido (IVC) de todos los ítems y subítems. Resultados: El instrumento obtuvo el IVC de 0,89. Ítems y subítems < 0,8 fueron modificados o excluidos, y la apariencia del material fue considerada buena. Conclusión: El instrumento educativo obtuvo concordancia adecuada entre los jueces y fue validado.

DESCRIPTORES: Pie diabético; Neuropatías diabéticas; Úlcera del pie; Estudios de validación; Estomaterapia.

\section{INTRODUCTION}

Diabetes Mellitus (DM) is a chronic disease caused by a heterogeneous group of metabolic disorders that result from malfunctioning in the secretion and/or action of insulin, leading to hyperglycemia and consequent alterations in the metabolism of carbohydrates, proteins and lipids, causing complications long-term ${ }^{1}$.

The disease affects about 387 million people around the world and it is estimated to increase to 592 million until $2035^{2}$. The frequency of DM is considered epidemic and attributed to growth, population aging, and lifestyle changes related to obesity, inactivity and food ${ }^{3}$.

The disease has an impact on quality of life (QoL), and education and health promotion measures are described as effective in preventing complications of the disease. Primary prevention refers to changes in lifestyle habits, with emphasis on food and physical activity, and secondary refers to metabolic control to minimize microangiopathic complications ${ }^{4-6}$.

Diabetic foot is one of the chronic complications of the disease, described as "soft tissue infection, ulceration and/ or destruction associated with neurological changes and various degrees of peripheral arterial disease in the lower limbs". Diabetic polyneuropathy is the main risk factor for ulceration and results in loss of protective sensitivity related to nerve fiber lesions due to endoneural ischemia of the microcirculation and metabolic changes due to prolonged exposure to hyperglycemia. Complications related to the motor nervous system are characterized by muscular atrophy and deformities of the foot (claw or hammer fingers, arch accentuation and metatarsal prominences), with the possibility of abnormal gait. Changes in the autonomic nervous system are characterized by decreased perspiration of the feet, dry skin, cracks and fissures that may result in an increased risk of bacterial or fungal infection ${ }^{1,5}$.

Trauma, limited joint mobility and abnormal plantar pressure due to deformities associated with decreased sensitivity are the main risk factors for ulceration. People with DM have a $25 \%$ risk of developing foot ulcers throughout life, and diabetic foot complications account for $40 \%$ to $70 \%$ of non-traumatic lower limb amputations. Approximately $85 \%$ of the amputations are preceded by foot ulcerations. The estimated mortality after five years of ulceration is $50 \%$ and increases to $70 \%$ after five years of amputation ${ }^{4,7}$. The risk and frequency of repeated amputations have significant regional differences associated with socioeconomic factors, availability of footwear and measures to prevent secondary 
complications ${ }^{4}$. Amputations have an impact on the health system, mortality and QoL, affecting self-image, self-esteem and the role of the individual in the family and in society $y^{8,9}$.

The clinical evaluation for traceability and identification of persons at risk of ulceration covers the clinical history and examination of the feet for the identification of neurological dysfunctions and areas of plantar pressure ${ }^{7,10}$.

Self-care education should involve clear guidelines on the disease and risks of complications, both for the client and its family members or legal guardians, in order to stimulate adherence to treatment and changes in lifestyle. Emphasis should be given to examination, care and signs of complications on the feet, guidance on shoes, nails and the necessity for glycemic control ${ }^{7,9}$.

The difficulty and scarcity of physical, human, and material resources in many health services in Brazil puts diabetes education at risk, and educational materials have assumed an important role in the teaching-learning process and empowerment of this clientele, making it capable of understand the actions that influence its health, emphasizing the importance of self-care ${ }^{11}$.

Printed information materials help the education process for self-care and the interaction between the client and the educator, facilitating the understanding of the disease, adapting to new concepts and overcoming difficulties ${ }^{12-14}$. Images and written guidelines allow a better understanding of the problem, reinforcing verbal information and serving as a guideline in case of doubt. Teaching and learning instruments in health should be developed for specific diseases, based on scientific evidence and with language accessible to the population at risk ${ }^{12-14}$.

In order to contribute to diabetes education, this study aimed to elaborate and validate the content of an educational instrument with health promotion actions for self-care of people with peripheral neuropathy due to diabetes.

\section{METHODS}

Study of methodological approach of quantitative type structured in two stages: elaboration of the educational instrument and validation of content.

The educational instrument was elaborated after a bibliographical survey realized in the databases Virtual Health Library, SciELO and LILACS/Database of
Nursing (BDENF); the search terms were "diabetic foot", "diabetic neuropathy" and "foot ulcer", selected in the Medical Subject Headings (MeSH) and Health Sciences Descriptors (DeCS), with descriptors and keywords in English, Portuguese and Spanish. The images were obtained by photographs taken by the authors with consent for use of the image.

The information was written in a language accessible to the lay population, addressing the topic diabetes, prevention guidelines, signs and symptoms of primary and secondary complications of peripheral neuropathy, hygiene, moisturization and foot inspection, nail care and shoe suitability. The printed material was titled Guidelines for People with Diabetic Peripheral Neuropathy - Preventing Foot Wounds.

\section{Validity of content}

The educational instrument was submitted to the evaluation of a committee of six specialists (judges) composed of two stomatherapist nurses, a podiatry nurse, a vascular surgeon, an endocrinologist and a physiotherapist (orthotist and prosthetist). The material for validation was sent by correspondence after formal invitation to the specialists and signing of the free and informed consent form.

The instrument was evaluated for the comprehensiveness, pertinence and clarity of each item and subitem and also its general appearance. The evaluation form included spaces for comments and/or suggestions. The instruments were analyzed and the data organized, grouped and presented in the form of absolute numbers and percentages. The acceptable rate of concordance between the judges was considered $80 \%{ }^{15}$.

The content validity score (CVI) score was calculated using the sum of agreement of the items scored by 3 or 4 by the specialists. Items that received scores 1 or 2 were reviewed or deleted. To perform this calculation, it was used Eq. 1:

$$
\mathrm{CVI}=\frac{\text { Number of answers } 3 \text { or } 4}{\text { Total number of answers }}
$$

Following the definitive changes, the final artwork and diagramation were realized by specialized audiovisual technical assistance and the material was printed and reproduced on couche paper specifically for the printing 
of figures. The page size was half sheet $(15 \times 21 \mathrm{~cm})$ in landscape format and finished with staple, trim and fold.

The research project was approved by the Research Ethics Committee of the Faculty of Medical Sciences of the State University of Campinas (UNICAMP) (opinion 1054/2010).

\section{RESULTS}

From the review, selection and adaptation of the contents to the composition of the educational material, the following contents resulted: introduction on diabetes, how to prevent complications of diabetes, health care, nail care, shoe choice and information of interest to the user.

As a result of the validation process, the educational instrument obtained a general CVI of 0.89. Table 1 specifies the items and subitems of the instrument evaluated by the judges and its respective CVI.

The modifications made in the material were established according to the suggestions and/or comment of the judges and it are described below:

\section{Items modified by $\mathrm{CVI}<0.8$}

In the item "Talking about diabetes", it was suggested to broaden and detail the diseases caused by neuropathy. It has been added: “... it may evolve to heart disease, blindness, decrease or loss of function of the kidneys and amputations", as well as the expression "... loss of sensitivity to pain, pressure and temperature (cold and hot).”

In the item "Taking Care of Your Foot Health Examine Your Feet," one of the judges questioned how a patient with impaired visual acuity would examine her feet. The questioning was considered valid, including: "Examine your feet daily; if you find it difficult to see them ask for help or use a magnifying glass or magnifying lens."

In the item "Nail Care - Nail Moisturizing", it was added, at the suggestion of one of the judges: "If you notice spots and deformities on the nails, consult a specialist." In the last paragraph of the same item, "a specialist" by "a specialized service".

In the item "Choosing the shoe", the suggested suggestion was accepted and the text became: "The most appropriate shoe is the one that comfortably accommodates your feet" and also "Look for information on therapeutic footwear."
In the item "Information of interest", 33.3\% of the judges considered the appointment of the "podologist" as the specialized nail care professional not relevant; also considered this information unclear and not very comprehensive, and it was decided to exclude the name of this professional. The term "orthopedic footwear" was replaced by "therapeutic footwear" at the suggestion of one of the judges.

Items modified with suggestions of judges and agreement of the authors, although CVI $>0.8$

In the item "Introduction", it was suggested by one of the judges to add the phrase "... especially heart, kidneys, nerves and blood vessels". The authors found it pertinent and the guide was changed.

One of the judges suggested changing the title "Preventing Complications" to "Preventing foot wounds," focusing on complications. This alteration was deemed pertinent and realized.

In the item "Taking care of its health", the judges considered that the control of the blood pressure had no relation with the objective of the material. For this reason, its opted to maintain only emphasis on glycemic control.

In the same item, it was suggested to clarify how smoking interferes with diabetic health and, therefore, added that "... smoking increases the clogging of diabetic blood vessels."

Considering the suggestion of one of the judges to cite the importance of the risk assessment of this population, the term "his doctor" was replaced by "a specialist" and "at least once a year was added to assess his risk to develop a sore foot."

In the item "Choosing the shoes," one of the judges suggested adding that the type of socks most indicated, as well as seamless cotton, should be "white".

Also excluded was the term "rigid insoles" and maintained only "silicone insoles are not indicated for neuropathy", so there would be no misinterpretation.

In the item "Information of interest", the phrase "The endocrinologist and the general practitioner are the professionals who can help him in the control of diabetes" was added by consensus among the authors, and was also replaced "the specialist in podiatry and stomatherapy" by " the nurse stomatologist and other specialists are best suited for the treatment of wounds and problems with the nails." 
Table 1. Content validity index (CVI) results of the items and sub-items evaluated by the judges.

\begin{tabular}{|c|c|c|c|c|}
\hline \multirow[b]{2}{*}{ Evaluated items } & \multicolumn{4}{|c|}{ CVI Results } \\
\hline & Scope & Relevance & Clarity & $\begin{array}{c}\text { General } \\
\text { appearance }\end{array}$ \\
\hline Introduction & 1 & & & $1^{*}$ \\
\hline Talking about diabetes & 0.84 & 1 & $0.5^{\star}$ & \\
\hline Preventing complications & 1 & 1 & $1 *$ & \\
\hline \multicolumn{5}{|l|}{ Caring for your health } \\
\hline Blood glucose control & & $0.84 *$ & $0.84 *$ & \\
\hline Exercises & & 0.84 & 1 & \\
\hline Smoking & & 1 & $0.84 *$ & \\
\hline Food & & 1 & 1 & \\
\hline Medication & & 1 & 1 & \\
\hline Monitoring & & 1 & 1 & \\
\hline \multicolumn{5}{|l|}{ Caring for the health of your feet } \\
\hline Watching the feet & & 0.84 & 0.84 & \\
\hline Hygiene & & 1 & 0.84 & \\
\hline Dry & & 1 & 1 & \\
\hline Moisturize & & 1 & 1 & \\
\hline Massage & & 0.84 & 0.84 & \\
\hline Prevent burn & & 1 & 0.84 & \\
\hline To examine & & 0.84 & $0.66^{*}$ & \\
\hline \multicolumn{5}{|l|}{ Caring for nail health } \\
\hline Cut & & 0.84 & 0.84 & \\
\hline Moisturization & & $0.66^{*}$ & $0.66^{*}$ & \\
\hline To remove & & 1 & 1 & \\
\hline Specialist & & $0.84 *$ & 1 & \\
\hline \multicolumn{5}{|l|}{ Choosing the shoe } \\
\hline Barefoot & & 1 & 1 & \\
\hline Soft shoe & & $0.66^{*}$ & $0.66^{*}$ & \\
\hline To buy shoe & & 0.84 & 0.84 & \\
\hline Special shoes & & 0.84 & 0.84 & \\
\hline Socks & & 1 & $0.84^{*}$ & \\
\hline To examine shoe & & 1 & 0.84 & \\
\hline Comfortable shoes & & 0.84 & 0.84 & \\
\hline Useful Information & 1 & & & \\
\hline Podologist & & $0.66^{*}$ & $0.5^{*}$ & \\
\hline Podiatrician or Stomatherapist & & 1 & $0.84 *$ & \\
\hline Orthopedic footwears & & 1 & $0.66^{*}$ & \\
\hline Doubts & & 0.84 & 0.84 & \\
\hline \multicolumn{5}{|l|}{ General appearance } \\
\hline Diagramming & & & & 1 \\
\hline Preview & & & & 1 \\
\hline Understanding & & & & 1 \\
\hline Grouping & & & & 0.84 \\
\hline Sequence & & & & 1 \\
\hline Theoretical foundation & & & & 0.84 \\
\hline
\end{tabular}

* Items modified, reformulated and/or withdrawn. 


\section{DISCUSSION}

The process of preparing an educational booklet is of great importance, as it guarantees the continuity of care at home, aiming for adequate care, making people affected by diabetes responsible for the success of its treatment, actively participating in the behaviors proposed by the health team ${ }^{12}$.

Educational strategies broaden teaching-learning possibilities and, when employed appropriately, help in the acquisition of knowledge, skills and attitudes in the management of diabetes ${ }^{11}$. This was also demonstrated in a almost experimental study realized in Mexico, which compared the traditional method with participatory communication, proving that the participatory method favored learning and the choice of conduits for the care of the feet of people with diabetes ${ }^{14}$.

Another study corroborates that the use of educational material with images through simplified models, illustrative folders, serial albums, pamphlets, posters, leaflets, followed by guidelines by health professionals produces satisfactory results during teaching-learning ${ }^{13}$.

Services for preventing complications in the feet of people with diabetes should be structured according to national guidelines, minimizing variations in clinical practice and ensuring different levels of care organization for people with diabetes and feet problems ${ }^{1}$. However, the organization and access to feet care services and the availability of skilled health professionals still present significant regional differences that interfere in the care of this population ${ }^{7,10}$.

Several studies point out that a high percentage of lower limb amputations in people with DM is avoidable and that feet ulcerations represent the main risk factor ${ }^{4,16}$. Educational approaches should emphasize the prevention of the occurrence of ulcerations based on daily and adequate care of the lower limbs and periodic examination of the feet, aiming to identify early changes, facilitating interventions and avoiding the development of complications ${ }^{10,17}$.

Education should be directed to improve knowledge, behavior and motivate adherence to self-care ${ }^{10}$. Consensus on diabetes, with recommendations for prevention of feet ulcerations, emphasize metabolic control, risk classification, feet evaluation and shoe suitability as essential measures for care ${ }^{4,6,7,10}$.

Persistent hyperglycemia and time of diabetes are the primary primary risk factors for peripheral neuropathy. Glycemic control significantly reduces the chronic complications of the disease and, in addition to glycosuria and fasting glycemia dosages, several methods are currently available for this purpose, such as glycemic control in the long term by means of glycated hemoglobin tests and detection of fluctuations in glycemia by means of self-monitoring of capillary glycemia (SMCG) and continuous monitoring of glucose in interstitial fluid $(\mathrm{MGII})^{7,10,17}$

Diabetic polyneuropathy is present in $50 \%$ of patients older than 60 years with type $2 \mathrm{DM}, 30 \%$ of patients in hospital clinical care and $20 \%$ to $25 \%$ of patients in primary care ${ }^{18}$. The perception and recognition of symptoms such as paresthesia, burning sensation, needle or twinge in the plantar region or loss of sensation with decreased sensation of pain and temperature perception are essential for the prevention of secondary complications of the disease ${ }^{6,19,20}$. Monitoring through insensitivity screening, evaluation of sensory, motor, vibratory, painful and reflex changes and observation of neuropathic deformities of the feet are also essential as a strategy to prevent ulcerations ${ }^{6,7,19}$.

Neurological tests for sensitivity assessment, tendon reflexes, and blood pressure and heart rate measurements should be performed according to the risk classification or at least annually by a specialist as a measure of control and prevention of ulcerations ${ }^{4}$.

The suitability of footwear is part of both prevention and treatment of ulcers ${ }^{4,6}$. The selection of footwear should consider the classification of risk of ulceration and be prescribed according to the Brazilian Association of Technical Standards (ABNT) and the National Institute of Metrology, Standardization and Industrial Quality (Inmetro), which have technical data for approval of footwear ${ }^{21}$. The user needs understanding and guidance on feet protection risks and measures related to the use of footwear, socks, insoles and orthoses to adhere to treatment $t^{10}$.

Early diagnosis of diabetic foot is the most effective measure for the prevention of ulcerations and amputations. The person with DM should be part of an interdisciplinary 
therapeutic plan that guarantees specialized treatment, provision of adequate footwear and education ${ }^{6,7,10}$.

A study on health education strategies used for teaching and learning of people with diabetes mellitus and peripheral neuropathy and another on risk assessment for diabetic foot ${ }^{23}$ have shown that health education is paramount and guarantees efficacy of self-care, change of habits and improvement of $\mathrm{QoL}$ texts and photographic illustrations that may contribute to the health education process of people with peripheral neuropathy due to diabetes and, consequently, to the prevention of primary and of the disease. The limitations of the study refer to the necessity to test the instrument with the target audience.

\section{AUTHORS CONTRIBUTION}

\section{CONCLUSION}

The final instrument of this study obtained the CVI of 0.89 , with adequate agreement among the judges, and was therefore validated. It has been shown to be comprehensive and pertinent, with clear and easy-tounderstand information, good appearance, informative
Conceptualization, Kaizer UAO and Araujo VS; Methodology, Kaizer UAO, de Araujo VS and Dantas SRPE; Investigation, Kaizer UAO and Araujo VS; Writing - First version, Kaizer UAO and Araujo VS; Writing - Review \& Editing; Kaizer UAO and Araujo VS; Writing - Review and Editing, Dantas SRPE.

\section{REFERENCES}

1. Sociedade Brasileira de Diabetes. Diretrizes da Sociedade Brasileira de Diabetes (2017-2018). São Paulo: Clannad; 2017.

2. International Diabetes Federation. IDF Diabetes Atlas. 6a ed. Available at: http://www.idf.org/diabetesatlas.

3. Hingorani A, La Muraglia GM, Henke $\mathrm{P}$, Meissner $\mathrm{MH}$, Loretz $\mathrm{L}$, Zinszer KM, et al. The management of diabetic foot: a clinical practice guideline by the Society for Vascular Surgery in collaboration with the American Podiatric Medical Association and the Society for Vascular Medicine. J Vasc Surg. 2016;63(Suppl 2): S3-21. doi: 10.1016/j.jvs.2015.10.003.

4. Bakker K, Apelqvist J, Lipsky BA, Van Netten JJ, International Working Group of Diabetic Foot. The 2015 IWGDF guidance documents on prevention and management of foot problems in diabetes: development of an evidence-based global consensus. Diabetes Metab Res Rev. 2016;32(Suppl 1):1-6. doi: 10.1002/dmrr.2694.

5. Tuttolomondo A, Maida C, Pinto A. Diabetic foot syndrome: immune-inflammatory features as possible cardiovascular markers in diabetes. World J Orthop. 2015;6(1):62-76. doi: 10.5312/wjo.v6.i1.62.

6. Brasil. Ministério da Saúde. Secretaria de Atenção à Saúde. Departamento de Atenção Básica. Manual do pé diabético: estratégias para o cuidado da pessoa com doença crônica. Brasília, DF: Ministério da Saúde; 2016.

7. National Institute for Health and Care Excellence. Diabetic foot problems: prevention and management. NICE guideline (NG19). Mancherter: NICE; 2015.

8. Hoban C, Sareen J, Henriksen CA, Kuzyk L, Embil JM, Trepman E. Mental health issues associated with foot complications of diabetes mellitus. Foot Ankle Surg. 2015;21(1): 49-55. doi: 10.1016/j.fas.2014.09.007.

9. Salomé GM, Pellegrino DMS, Blanes L, Ferreira LM. Self-esteem in patients with diabetes mellitus and foot ulcers. J Tissue Viability. 2011;20(3):100-6. doi: 10.1016/j. jtv.2010.12.004.
10. Bus SA, Van Netten JJ, Lavery LA, Monteiro-Soares M, Rasmussen $A$, Jubiz $Y$, et al. IWGDF guidance on the prevention of foot ulcers in at-risk patients with diabetes. Diabetes Metab Res Rev. 2016;32(Suppl 1):16-24. doi: 10.1002/dmrr.2696.

11. Menezes, LCG. Autocuidado da pessoa com diabetes e pé em risco: contribuição ao cuidado clínico de enfermagem [dissertação]. Fortaleza (CE): Universidade Estadual do Ceará, Centro de Ciências da Saúde; 2013.

12. Torres HC, Candido NA, Alexandre LR, Pereira FL. O processo de elaboração de cartilhas para orientação do autocuidado no programa educativo em diabetes. Rev Bras Enferm. 2009;62(2): 312-6. doi: 10.1590/5003471672009000200023.

13. Saurabh S, Sarkar S, Selvaraj K, Kar SS, Kumar SG, Roy G. Effectiveness of foot care education among people with type 2 diabetes in rural Puducherry, India. Indian J Endocr Metab. 2014;18(1):106-10. doi: 10.4103/2230-8210.126587.

14. Pérez Rodríguez MC, Godoy S, Mazzo A, Nogueira PC, Trevizan MA, Mendes IAC. Cuidado en los pies diabéticos antes y después de intervención educativa. Enferm glob. 2013; 12(29):43-52.

15. Polit DF, Beck CT. Fundamentos de pesquisa em enfermagem: avaliação de evidências para as práticas da enfermagem. 7a ed. Porto Alegre: Artmed; 2016.

16. Brasil. Ministério da Saúde. Secretaria de Atenção à Saúde. Departamento de Atenção Básica. Avaliação e cuidados com os pés de pessoas com diabetes mellitus na atenção básica. In: Estratégias para o cuidado da pessoa com doença crônica: diabetes mellitus. Cadernos de Atenção Básica n. 36. Brasília: Ministério da Saúde; 2013. p. 91-106.

17. American Diabetes Association. Standards of medical care in diabetes - 2014. Diabetes Care. 2014;37(Suppl 1):S14-80. doi: $10.2337 /$ dc14-S014. 
18. Tapp R, Shaw J. Epidemiology of diabetic neuropathy. In: Tesfaye S, Boulton AJM (Ed.). Diabetic neuropathy. Oxford: Oxford Diabetes Library; 2009. p. 1-8.

19. Caiafa JS, Castro AA, Fidelis C, Santos VP, Silva ES, Sitrângulo Jr CJ. Atenção integral ao portador de pé diabético. J vas bras. 2011;10(4Suppl 2):1-32. doi: 10.1590/S167754492011000600001.

20. Boell JEW, Ribeiro RM, Silva DMGV. Fatores de risco para o desencadeamento do pé diabético. Rev Eletr Enf. 2014;16(2):386-93. doi: 10.5216/ree.v16i2.20460.

21. Pedrosa HC, Tavares SF, Saigg MAC, Batista MCP, Carvalho PS. Programa Passo a Passo (Step by Step) - Fichas clínicas.
In: Pedrosa HC, Vilar L, Boulton AJM (Ed.). Neuropatias e pé diabético. Rio de Janeiro: AC Farmacêutica; 2014. p. 144-59.

22. Menezes LCG, Guedes MVC, Moura NS, Oliveira RM, Vieira LA, Barros AA. Estratégias educativas para pessoas diabéticas com pé em risco neuropático: síntese de boas evidências. Rev Eletr Enf. 2016;18:e1197. doi: 10.5216/ree. v18.40281.

23. Bezerra GC, Santos ICRV, Lima JC, Souza MAO. Avaliação do risco para desenvolver pé diabético na atenção básica ESTIMA, Braz J Enterostomal Ther. 2015;13(3). 